\title{
Cultural conditions for maximum alpha- amylase production by Penicillium notatum IBGE 03 using shaken flask technique of submerged fermentation
}

\author{
Kashif Ahmed ${ }^{1 *}$, Seharish Munawar ${ }^{2}$ and Muhammad Ansar Khan ${ }^{3}$ \\ 1. Department of Chemistry, N.E.D. University of Engineering \& Technology, Karachi, Pakistan \\ 2. Directorate of Fisheries Sindh, Research and Development, Karachi, Pakistan \\ 3. Department of Chemical Engineering, N.E.D. University of Engineering and Technology, Karachi, Pakistan. \\ *Corresponding author's email: kashif25473@yahoo.com
}

Citation

Kashif Ahmed, Seharish Munawar and Muhammad Ansar Khan. Cultural conditions for maximum Alpha-Amylase production by Penicillium notatum IBGE 03 using shaken flask technique of submerged fermentation. Pure and Applied Biology. Vol. 4, Issue 3, 2015, pp 306-312. http://dx.doi.org/10.19045/bspab.2015.43005

Received: 25/04/2015 Revised: 18/05/2015

Accepted: 10/06/2015

\section{Abstract}

Ever increasing biotechnological industries require an enlarged survey of microorganisms which might be useful for industries. In the present work optimization parameters for alpha amylase production by Penicillium notatum IBGE 03 in submerged fermentation were studied. Various agricultural based by-products (sunflower waste, cotton stalk, rice husk, date syrup and molasses) were used as sources of carbon. Optimal conditions for the production of $\alpha$-amylase $(6.58 \mathrm{U} / \mathrm{mL})$ by $P$. notatum IBGE 03 were observed when the strain was grown on culture medium M1 containing corn steep liquor as a source of nitrogen, molasses as a source of carbon after $48 \mathrm{~h}$ of incubation at $30^{\circ} \mathrm{C}$, initial $\mathrm{pH} 5.5$, inoculum size of $5 \times 10^{6}$ conidia in $50 \mathrm{~mL}$ of culture medium and agitation rate of $150 \mathrm{rev} / \mathrm{min}$. The strain was proved thermo (up to $60^{\circ} \mathrm{C}$ ) and $\mathrm{pH}$ (up to 9.0) stable so it might be a potential strain for industrial utilization.

Key words: Alpha-amylase; Penicillium notatum IBGE 03; Optimization.

\section{Introduction}

Alpha-amylase (Enzyme Commission No. is 3.2.1.1) is an extracellular enzyme, which splits $\alpha-1,4-$ glycosidic bonds of starch and produces glucose, maltose and alpha limit dextrin[1].The substrate of amylase is starch, which is a polysaccharide and composed of two types of polymers amylose and amylopectin. Starch is composed of 20$25 \%$ amylose, which is a linear chain of glucose units joined by $\alpha-1$, 4- glycosidic bonds and about 75-80 \% amylopectin, which is branched macro molecule of glucose in which 1,6- glycosidic bonds are also present [1].

Amylases are one of the most widely used commercial enzymes whose range of application has broadened in numerous areas such as food, medicinal, clinical and analytical chemistry. They are used in starch hydrolysis they also catch uses in pharmaceutical, food, baking, brewing, paper, detergent and textile industries. These are essential enzymes used in starch treating activities for hydrolysis of 
polysaccharides such as starch into simple sugar components [1].

Agricultural based by-products in Pakistan are usually disposed of by environment nonfriendly manner. So in the present study some of them were used as sources of carbon in order to reduce pollution related issues. In literature a number of nonconventional carbon sources such as starch, date syrup, sunflower waste, oilcakes, cassava starch, potato peel, fruit peel, corn and tapioca have been reported in submerged fermentation for various enzymes production [2, 3]. The present study shows the optimized cultural conditions for the maximum production of alpha-amylase by Penicillium notatum IBGE 03 using different wastes as sources of carbon.

\section{Materials and Methods}

\section{Strains}

Strain of Penicillium notatum IBGE 03 was obtained from the Institute of Biotechnology \& Genetic Engineering University of Sindh and the culture was maintained as followed by Dahot [4]. In the present study slants of 4 days old were used for inoculation.

\section{Conidia count}

Number of conidia of each fungus was counted by haemocytometer (BOE 13, Boeco Germany). Spore suspension was maintained about $4 \times 10^{6}$ conidia/mL and they were added to $50 \mathrm{~mL}$ of fermentation media in $250 \mathrm{~mL}$ flask.

\section{Hydrolysis of agriculture waste}

Each agricultural based by-product (cotton stalk, sunflower waste and rice husk) were treated as reported earlier [2].

\section{Alpha-amylase activity}

Alpha-amylase activity was determined by Bernfeld method [5].One unit of $\alpha$-amylase is the amount of enzyme that will release 1 $\mathrm{mg}$ of reducing sugar in $3 \mathrm{~min}$ at $50^{\circ} \mathrm{C}$ and $\mathrm{pH} 7.0$.

\section{Optimization of Enzyme Production Parameters}

All experiments were done in such a way that the parameter optimized in one experiment was fixed in the subsequent experiments for the maximum production of enzyme. Following were parameters:

\section{Culture media}

First of all the most suitable culture medium was determined. For optimization of $\alpha$ Amylase production following culture media were used having composition $(\mathrm{g} / \mathrm{L})$.

M1: Dextrose 10, Peptone 5, Epsom salt 5, $\mathrm{KH}_{2} \mathrm{PO}_{4}$ 5, Common salt 2.5, ferrous sulphate hepta hydrate $0.01, \mathrm{ZnSO}_{4} .7 \mathrm{H}_{2} \mathrm{O}$ $0.002, \mathrm{MnSO}_{4} . \mathrm{H}_{2} \mathrm{O} \quad 0.001$ and thiamine hydrochloride 0.001 [6].

M2: soluble starch 20, $\mathrm{NH}_{4} \mathrm{NO}_{3} 10$, $\mathrm{KH}_{2} \mathrm{PO}_{4}, 14, \mathrm{KCl}, 0.5$, Epsom salt 0.1, $\mathrm{FeSO}_{4} .7 \mathrm{H}_{2} \mathrm{O}, 0.01$ [7].

M3: $\mathrm{NaCl} 0.8, \mathrm{KCl} 0.8, \mathrm{CaCl}_{2} 0.1, \mathrm{Na}_{2} \mathrm{HPO}_{4}$ 2.0, $\mathrm{MgSO}_{4} 0.2, \mathrm{FeSO}_{4}$ 0.1, 8.0 Glucose, $\mathrm{NH}_{4} \mathrm{Cl} 2.0$ [8].

M4: $\mathrm{Zn} \quad \mathrm{SO}_{4} .7 \mathrm{H}_{2} \mathrm{O} \quad 0.062, \mathrm{FeSO}_{4} 0.068$, copper sulphate pent hydrate 0.0001 and wheat bran 100 [9].

\section{Incubation time period}

After the determination of the most suitable culture medium, optimum incubation time period was determined. It was done by growing the strain on M1 at various time periods from 24-240 h.

\section{Carbon sources}

After the optimization of incubation time the most suitable carbon source was determined. It was done by replacing the glucose (control) of culture medium (M1) by various wastes including sunflower waste, cotton stalk, rice husk, which were hydrolyzed by $0.3 \mathrm{~N} \mathrm{H}_{2} \mathrm{SO}_{4}$ and $0.6 \mathrm{~N} \mathrm{H}_{2} \mathrm{SO}_{4}$. Date syrup and molasses were used $0.5 \%$ and $1 \%$ in place of glucose (control).

\section{Nitrogen sources}

After the determination of the most suitable carbon source various nitrogen sources were checked for maximum production of enzymes. It was done by replacing peptone of culture medium (M1) by corn steep 
liquor, casein, potassium nitrate, albumin, ammonium sulphate, urea and yeast extract.

\section{Incubation temperature}

The most suitable culture medium M1 (with the most suitable carbon and nitrogen source) was tested on varying temperature from $20-70^{\circ} \mathrm{C}$ to determine the most suitable incubation temperature for the production of enzyme.

\section{Initial pH of medium}

The initial $\mathrm{pH}$ of a medium has an effect on growth and productivity of microorganism. A range of $\mathrm{pH}$ from 4.0-9.0 was checked for maximum enzyme production.

\section{Inoculum size}

Productivity was also checked in terms of number of conidia in $50 \mathrm{~mL}$ of optimized culture medium in order to obtain the optimized inoculum size of culture medium. The number of conidia was counted by haemocytometer $(\mathrm{BOE} 13, \quad$ Boeco Germany).

\section{Agitation rate}

Effect of agitation rate was also checked for optimization at 50,100, 150, 200, 250 and $300 \mathrm{rev} / \mathrm{min}$ in orbital shaking incubator (SANYO Gallenkamp, PLC, UK).

\section{Results and Discussion} Effect of culture media

Effects of various culture media on $\alpha$ amylase production by $P$. notatum IBGE 03 after $24 \mathrm{~h}$, at temperature $30^{\circ} \mathrm{C}$, initial $\mathrm{pH}$ 6.0 , inoculum size $4 \times 10^{6}$ conidia and agitation rate $50 \mathrm{rev} / \mathrm{min}$ are presented (Fig. 1). The strain was grown on four different culture media i.e. M1, M2, M3 and M4. It was grown well on all types of culture media but production of $\alpha$-amylase was maximum (1.42 U/mL) on culture medium M1, which was selected for the following study of $\alpha$ amylase production.

\section{Effect of incubation time period}

The effects of incubation time periods on $\alpha$ amylase production by $P$. notatum IBGE 03 in $\mathrm{M} 1$ at temperature $30^{\circ} \mathrm{C}$, initial $\mathrm{pH} 6.0$, inoculum size $4 \times 10^{6}$ conidia and agitation rate $50 \mathrm{rev} / \mathrm{min}$ are plotted (Fig. 2). Activity of $\alpha$-amylase was measured at regular interval of $24 \mathrm{~h}$ and it was found that the maximum activity $(1.86 \mathrm{U} / \mathrm{mL})$ was observed after $48 \mathrm{~h}$ of incubation. On prolonged incubation enzyme activity was decreased, which might be due to denaturing of enzyme or synthesis of inhibiting metabolite [10]. Khan and Yadav [8] also reported incubation time period of $48 \mathrm{~h}$ for $\alpha$-amylase production by Aspergillus niger.

\section{Effect of carbon sources}

The effects of various carbon sources on $\alpha$ amylase production by $P$. notatum IBGE 03 after $48 \mathrm{~h}$ in $\mathrm{M} 1$ at temperature $30^{\circ} \mathrm{C}$, initial $\mathrm{pH}$ 6.0, inoculum size $4 \times 10^{6}$ conidia and agitation rate $50 \mathrm{rev} / \mathrm{min}$ are presented (Fig. 3 ). It was observed that $\alpha$-amylase activities were lower in case of $0.3 \mathrm{~N}$ sulphuric acid hydrolysed agriculture waste $(0.86,1.17$ and $0.97 \mathrm{U} / \mathrm{mL}$ for cotton stalk, sunflower waste and rice husk respectively) and $0.5 \%$ of molasses and date syrup (1.57 and $1.46 \mathrm{U} / \mathrm{mL}$ respectively). Activities of $\alpha$-Amylase were closed to or higher than control, glucose (1.86 $\mathrm{U} / \mathrm{mL}$ ) when $0.6 \mathrm{~N}$ sulphuric acid hydrolysed agriculture waste $(1.74,2.13$ and $1.84 \mathrm{U} / \mathrm{mL}$ for cotton stalk, sunflower waste and rice husk respectively) and $1 \%$ of molasses (2.43 $\mathrm{U} / \mathrm{mL})$ and date syrup $(2.24 \mathrm{U} / \mathrm{mL})$ were used. Matthias [7] reported starch as the appropriate carbon source for $\alpha$-amylase production by Aspergillus, Mucor and Rhizopus species.

\section{Effect of nitrogen sources}

The effects of various nitrogen sources on $\alpha$ amylase production by $P$. notatum IBGE 03 after $48 \mathrm{~h}$ in $\mathrm{M} 1$ containing molasses as carbon source at $30^{\circ} \mathrm{C}$, initial $\mathrm{pH}$ 6.0, inoculum size $4 \times 10^{6}$ conidia and agitation rate $50 \mathrm{rev} / \mathrm{min}$ are shown (Fig. 4). The strain showed the capability of utilizing well all types of nitrogen sources but corn steep liquor was found to be the best $(2.18 \mathrm{U} / \mathrm{mL}$ in $0.25 \%$ and $4.79 \mathrm{U} / \mathrm{mL}$ in $0.50 \%$ ). 


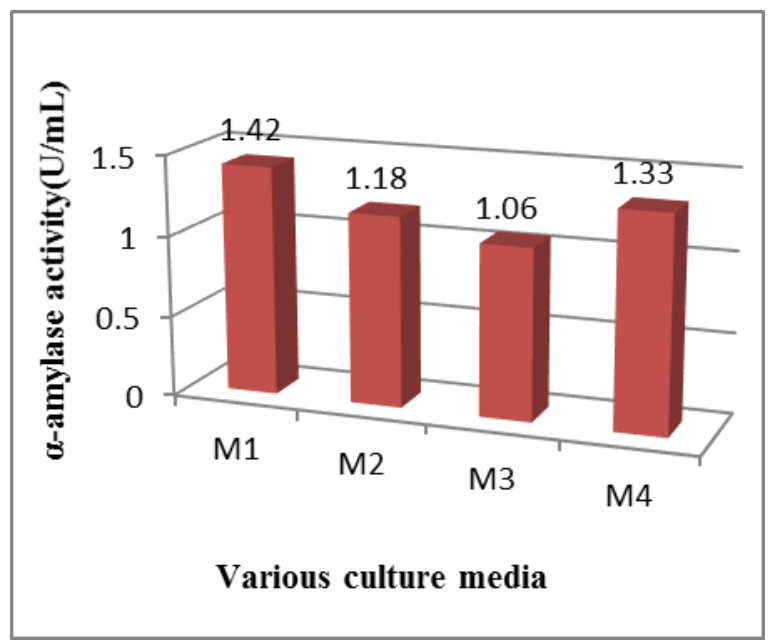

Fig. 1. Effects of various culture media on $\alpha$-amylase production by Penicillium notatum after $24 \mathrm{~h}$, at temperature $30^{\circ} \mathrm{C}$, initial $\mathrm{pH} 6.0$, inoculum size $4 \times 10^{6}$ conidia and agitation rate $50 \mathrm{rev} / \mathrm{min}$.

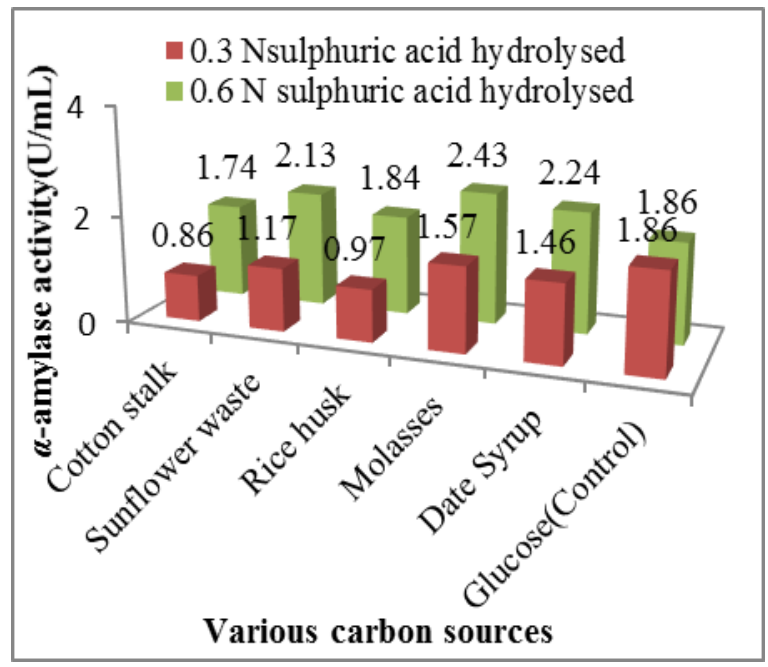

Fig. 3. Effects of various carbon sources on $\alpha$-amylase production by $P$. notatum after $48 \mathrm{~h}$ in $\mathrm{M} 1$ at $30^{\circ} \mathrm{C}$, initial $\mathrm{pH}$ 6.0 , inoculum size $4 \times 10^{6}$ conidia and agitation rate $50 \mathrm{rev} / \mathrm{min}$.

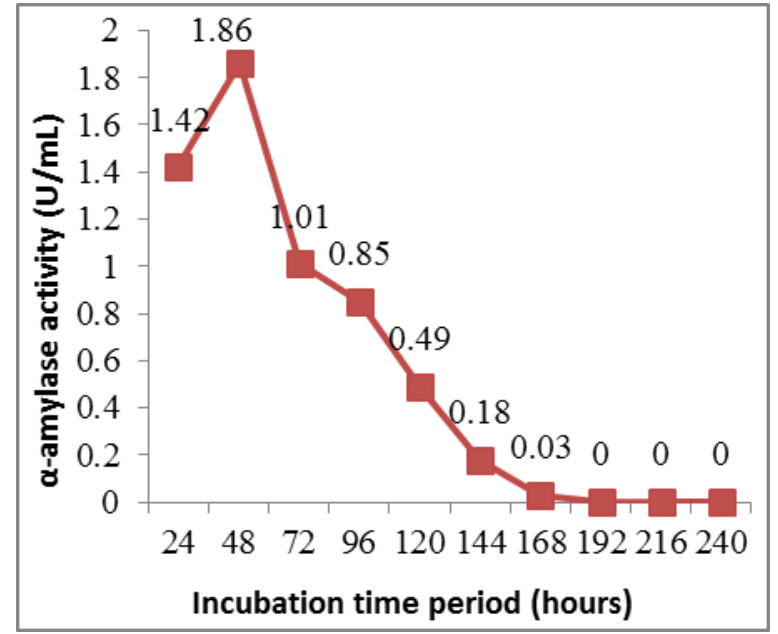

Fig. 2. Effects of incubation time periods on $\alpha$-amylase production by $P$. notatum in $\mathrm{M} 1$ at $30^{\circ} \mathrm{C}$, initial $\mathrm{pH} 6.0$, inoculum size $4 \times 10^{6}$ conidia and agitation rate $50 \mathrm{rev} / \mathrm{min}$.

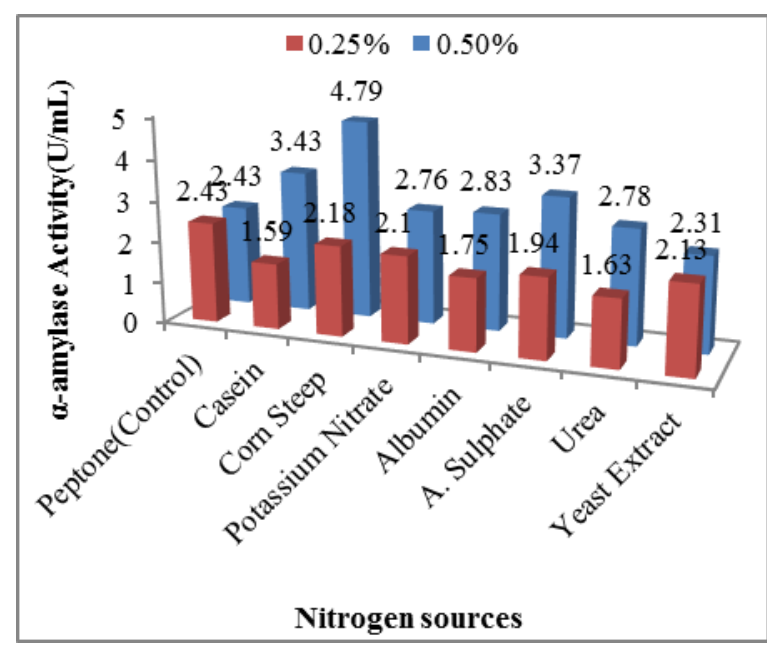

Fig. 4. Effects of various nitrogen sources on $\alpha$-amylase production by $P$. notatum after $48 \mathrm{~h}$ in $\mathrm{M} 1$ containing molasses as carbon source at $30^{\circ} \mathrm{C}$, initial $\mathrm{pH}$ 6.0, inoculum size $4 \times 10^{6}$ conidia and agitation rate $50 \mathrm{rev} / \mathrm{min}$. 


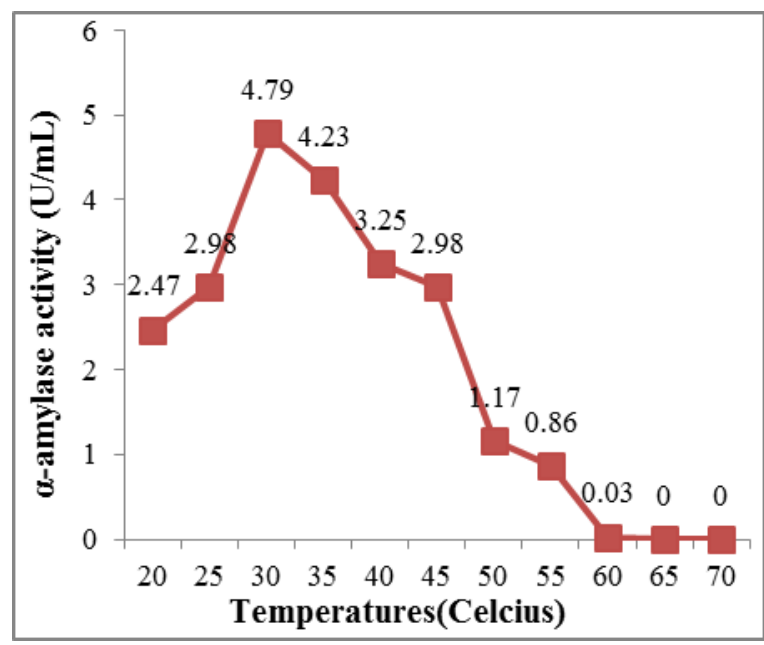

Fig. 5. Effects of incubation temperatures on $\alpha$-amylase production by $P$. notatum after $48 \mathrm{~h}$ in $\mathrm{M} 1$ containing molasses as carbon source, corn steep liquor as nitrogen source, at initial $\mathrm{pH} 6.0$, inoculum size $4 \times 10^{6}$ conidia and agitation rate $50 \mathrm{rev} / \mathrm{min}$.

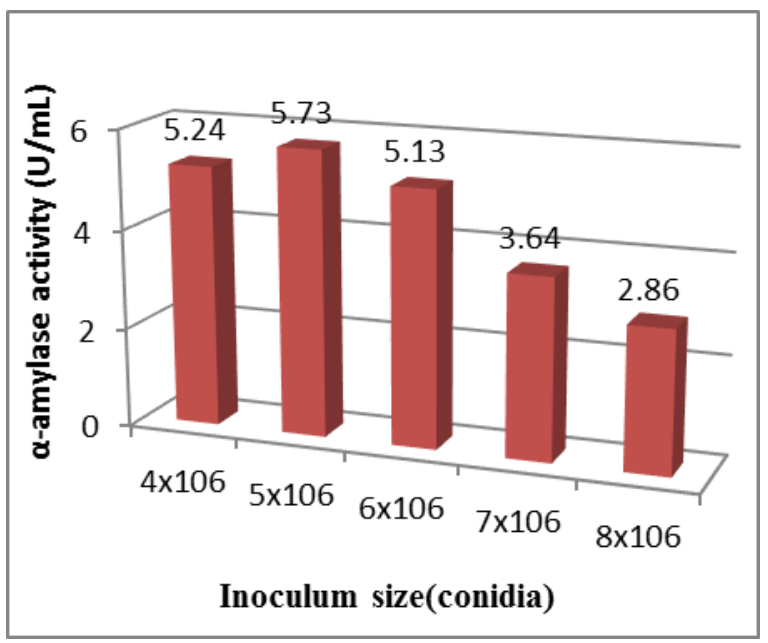

Fig. 7. Effects of inoculum sizes on $\alpha$-amylase production by $P$. notatum after $48 \mathrm{~h}$ in $\mathrm{M} 1$ containing molasses as carbon source, corn steep liquor as nitrogen source, at $30^{\circ} \mathrm{C}$, initial $\mathrm{pH} 5.5$

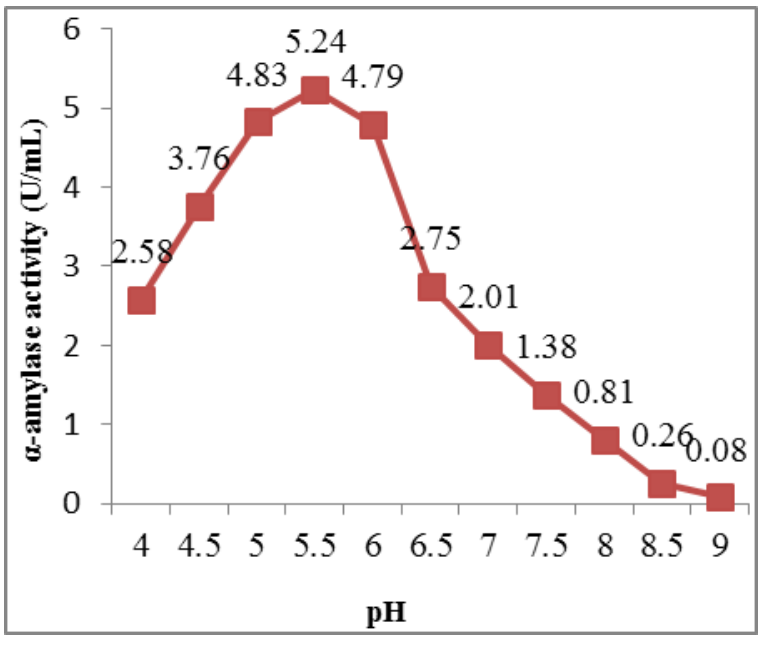

Fig. 6. Effects of initial $\mathrm{pH}$ of fermentation medium on $\alpha$ amylase production by P.notatum after $48 \mathrm{~h}$ in $\mathrm{M} 1$ containing molasses as carbon source, corn steep liquor as nitrogen source, at $30^{\circ} \mathrm{C}$, inoculum size $4 \times 10^{6}$ conidia and agitation rate $50 \mathrm{rev} / \mathrm{min}$.

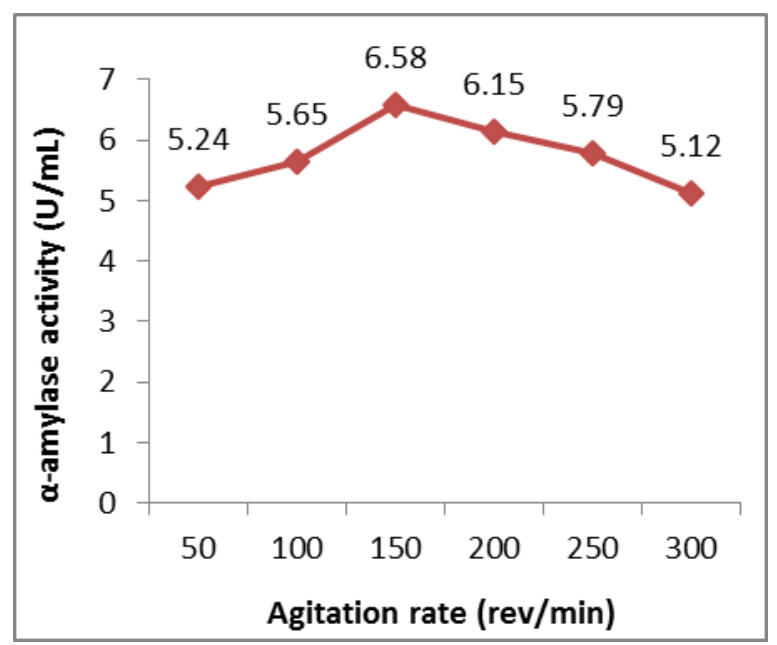

Fig. 8. Effects of agitation rates on $\alpha$-amylase production by $P$. notatum after $48 \mathrm{~h}$ in M1 containing molasses as carbon source, corn steep liquor as nitrogen source, at $30^{\circ}$ C, initial $\mathrm{pH} 5.5$ and inoculum size $5 \times 10^{6}$ conidia. 
Various nitrogen sources have been reported in literature for $\alpha$-amylase production for example Singh et al. [11] reported beef extract by Aspergillus fumigatus while Matthias [7] reported ammonium nitrate for Aspergillus, Mucor and Rhizopus species.

\section{Effect of temperature}

The effects of incubation temperatures on $\alpha$ amylase production by $P$. notatum IBGE 03 after $48 \mathrm{~h}$ in $\mathrm{M} 1$ containing molasses as carbon source, corn steep liquor as nitrogen source, at initial $\mathrm{pH}$ 6.0, inoculum size $4 \times 10^{6}$ conidia and agitation rate $50 \mathrm{rev} / \mathrm{min}$ are plotted (Fig. 5). The fermentation medium was incubated at a range of temperatures $20-70^{\circ} \mathrm{C}$. Activity of $\alpha$-amylase was the highest $(4.79 \mathrm{U} / \mathrm{mL})$ about $30^{\circ} \mathrm{C}$. Saleem \& Ebrahim [12] reported similar incubation temperature for $\alpha$-amylase production by Aspergillus niger and Rhizopus stolonifer. The strain showed thermo stability up to $60^{\circ} \mathrm{C}(0.03 \mathrm{U} / \mathrm{mL})$.

\section{Effect of initial pH}

The effects of initial $\mathrm{pH}$ of fermentation medium on $\alpha$-amylase production by $P$. notatum IBGE 03 after $48 \mathrm{~h}$ in M1 containing molasses as carbon source, corn steep liquor as nitrogen source, temperature $30^{\circ} \mathrm{C}$, inoculum size $4 \times 10^{6}$ conidia and agitation rate $50 \mathrm{rev} / \mathrm{min}$ are presented (Fig. 6 ). The range of $\mathrm{pH}$ (4.0 to 9.0) was studied and found that initial $\mathrm{pH}$ of 5.5 would be the optimum for maximum enzyme production $(5.24 \mathrm{U} / \mathrm{mL})$. After and before the $\mathrm{pH}$ the decrease in enzyme activity was observed. Saleem \& Ebrahim [12] have reported $\mathrm{pH}$ 6.0 as the appropriate for $\alpha$-amylase production by Aspergillus niger and Rhizopus stolonifer.

\section{Effect of inoculum size}

The effects of inoculum sizes on $\alpha$-amylase production by $P$. notatum IBGE 03 after 48 $\mathrm{h}$ in $\mathrm{M} 1$ containing molasses as carbon source, corn steep liquor as nitrogen source, at $30^{\circ} \mathrm{C}$, initial $\mathrm{pH} 5.5$ and agitation rate 50 rev/min are presented (Fig. 7). Flasks were added with $4 \times 10^{6}-8 \times 10^{6}$ conidia and maximum $\alpha$-amylase activity $(5.73 \mathrm{U} / \mathrm{mL})$ was observed when $5 \times 10^{6}$ conidia were added to the medium. Literature survey revealed that researchers used varying inoculum sizes $[3,13]$. Large inoculum size caused overgrowth and nutritional imbalance resulting less production of enzyme $[4,10,13]$.

\section{Effect of agitation rate}

The effects of agitation rates on $\alpha$-amylase production by $P$. notatum IBGE 03 after 48 $\mathrm{h}$ in $\mathrm{M} 1$ containing molasses as carbon source, corn steep liquor as nitrogen source, at $30^{\circ} \mathrm{C}$, initial $\mathrm{pH} 5.5$ and inoculum size $5 \times 10^{6}$ conidia are presented (Fig. 8). The fermentation medium was agitated at 50, 100, 150, 200, 250 and $300 \mathrm{rev} / \mathrm{min}$. $\alpha$-amylase activity was maximum $(6.58 \mathrm{U} / \mathrm{mL})$ at 150 rev/min. Literature survey revealed that researchers reported various agitation rates (100-200 rev/min) for enzymes production by different microorganisms $[4,10,13]$.

\section{Conclusion}

Optimal conditions for the production of $\alpha$ amylase $(6.58 \mathrm{U} / \mathrm{mL})$ by Penicillium notatum IBGE 03 were observed when the strain was grown on culture medium M1 containing corn steep liquor as a source of nitrogen, molasses as a source of carbon after $48 \mathrm{~h}$ of incubation at $30^{\circ} \mathrm{C}$, initial $\mathrm{pH}$ 5.5 , inoculum size of $5 \times 10^{6}$ conidia in 50 $\mathrm{mL}$ of culture medium and agitation rate of $150 \mathrm{rev} / \mathrm{min}$. The strain was proved $\mathrm{pH}$ (up to 9) and thermo stable (up to $60^{\circ} \mathrm{C}$ ) therefore can be used in industries for alphaamylase production.

\section{References}

1. Sundarram A. \& T. P. K. Murthy (2014). $\alpha$-amylase production and applications: $A$ review $J$ App \& Environ Microbiol 2(4): 166-175.

2. Ahmed K, Dahot MU, Haq Q \& Valeem EE (2011). Optimal Conditions of the Production of Commercial Enzyme by Penicillium Lilacinum by Culturing on 
Agroindustrial Waste. Int $J$ Biol Biotechnol 8(2):213-219.

3. Ahmed K, Valeem EE, Haq Q, Mehmood I \& Dahot MU (2014). Optimal Conditions for the Production of Industrial Enzymes by Aspergillus Niger Using Agricultural Wastes as sources of Carbon. FUUAST J Biol 4(2):129-136.

4. Dahot MU (1986). Biosynthesis of Invertase by Penicillium expansum. $J$ Pure App Sci 5(1): 23-26.

5. Bernfeld P (1955). Amylases $\alpha$ and $\beta$. Methods in Enzymology 1:49-58.

6. Burrel RG, Clayton CW, Gallegly MR \& Litty VG (1966). Factors Affecting the Antigenicity of the Mycelium of Three Species of Phytophthora. Phytopathology 56: 422-426.

7. Matthias, OC (2013). Optimization of $\alpha-$ amylase and glucoamylase production from three fungal strains isolated from Abakaliki, Ebonyi State. Eur J Exp Biol 3(4): 26-34.

8. Khan JA \& Yadav SK (2011). Production of alpha amylases by Aspergillus niger using cheaper substrates employing solid state fermentation. Int J Plant Anim and Environ Sci 3(1): 100-108.

9. Hayashida S \& Teramoto Y (1986).
Production and characteristics of raw starch digesting $\alpha$-amylase from protease negative Aspergillus ficum mutant. Appl Environ Microbiol 52(5): 1068-1073.

10. Mamma D, Kourtoglou E \& Christakopoulos P (2008). Fungal Multienzyme Production on Industrial By products of The Citrus-Processing Industry. Bioresour Technol 99: 23732383.

11. Singh S, Singh S, Bali V, Sharma L \& Mangla J (2014). Production of fungal amylases using cheap, readily available agri-residues, for potential application in textile industry. Bio Med Res Int p.1-9 (http://dx.doi.org/10.1155/2014/215748).

12. Saleem A \& Ebrahim MKH (2014). Production of amylase by fungi isolated from legume seeds collectedin Almadinah Almunawwarah, Saudi Arabia. J Taibah Uni Sci 8: 90-97.

13. Archana S \& Satyanarayana T (2011). Optimization of medium components and cultural variables for enhanced production of acidic high maltoseforming and $\mathrm{Ca}^{2+}$-independent $\alpha$-amylase by Bacillus acidicola. J Biosci Bioeng 111(5): 550-553. 